\title{
Effect of feeding swill feed supplemeted with chocolate cream waste on backfat thickness and body measurements in fattener weaner pigs
}

\section{Divyalakshmi*}

Department of Livestock Production Management, Madras Veterinary College, Chennai-7 (Tamil Nadu), India

\section{N. Kumaravelu}

Department of Livestock Production Management, Madras Veterinary College, Chennai-7 (Tamil Nadu), India

\section{Balan}

Department of Statistics and Computer Applications, Madras Veterinary College, Chennai -7(Tamil Nadu), India

\section{Thanga.Thamil Vanan}

Department of Livestock Production Management, Madras Veterinary College, Chennai-7 (Tamil Nadu), India

P. Tensingh Gnanaraj

TANUVAS, MMC, Chennai-51 (Tamil Nadu), India

*Corresponding author. E-mail: nandhi7121989@gmail.com

\section{Abstract}

Pig rearing on concentrate feed may not be economical because of higher market price of raw materials. The alternative source could be the use of swill feeding. Consequently, the impact of the swill feed on the backfat thickness and body measurements calls for investigation against any other alternative feed. Hence in the present study, an attempt has been made to compare the body measurements and backfat thickness in fattener piglets which were fed with swill feed (T1) vs. Those fed with chocolate cream waste supplemented with swill feed (T2). The statistical analysis of the data obtained in the present study revealed that there was highly significant $(P \leq 0.01)$ difference between body weight gain and backfat thickness (layer I and II) of both the group of piglets which were taken for trial starting from three months of age till five months of age. However, not significant difference $(P \geq 0.05)$ was noticed for body length and chest girth except in the pigs of 150 days age group. This study indicates that swill feed supplemented with chocolate cream waste could be used to reduce the feed cost since higher weight gain is achieved in a shorter time interval, increasing body measurements and backfat thickness compared to swill feed (T1) group of piglets.

Keywords: Backfat thickness, Body measurements, Fattener pigs, Swill feed

\section{Article Info}

DOI:10.31018/jans.v11i1.1986

Received: January 9, 2019

Revised: February 16, 2019

Accepted: February 23, 2019

\section{How to Cite}

Divyalakshmi, D. et al. (2019). Effect of feeding swill feed supplemeted with chocolate cream waste on backfat thickness and body measurements in fattener weaner pigs. Journal of Applied and Natural Science, 11(1): 155-157

\section{INTRODUCTION}

Intensive pig production systems have gained increasing interest in developing countries like India. The use of alternative feedstuffs and novel ingredients in swine diets has gained increasing popularity in the past few years. Pig rearing on concentrate feed may not be economical because of higher market price of raw materials. Feed cost accounts to about 70 per cent of the expense in intensive production (Singh and Islam, 2014). Hence, an alternate feeding system has to be explored for the least cost pig rearing. Recently swill feed or left over feed from hotels are increasingly used to economise the intensive pig production and thus can be used as alternative feed. Offlate even swill feed is becoming a costly affair because of scarcity of food produced (Banerjee, 2010).

The efficiency of pig production systems relies on the weight gain, body scoring etc. However, the backfat thickness and body measurements are considered as the major parameters to appraise the method of production. In pigs, major elements of backfat or subcutaneous fat consist of water, collagen, and lipid. The major composition of lipid in subcutaneous fat is triacylglycerol. Thus the amount of fat and feed intake affects the concentration of fatty acid in subcutaneous fat (Thomas et al., 2016). Consequently, the impact of the feeding systems in swine on the backfat thickness and body measurements calls for investigation against swill feed supplemented with chocolate cream waste. Hence in the present study, an at- 
tempt has been made to compare the body measurements and backfat thickness in fattener piglets which were fed with swill feed vs. those fed with swill feed supplemented with chocolate cream waste.

\section{MATERIALS AND METHODS}

Experimental location: The measurements were made from weaned fattener pigs maintained at Livestock Farm Complex, Madhavaram, Chennai. Pig sty having conventional open run and pen system, housing 10 - 13 fattening pigs, providing a floor space of $0.9 \mathrm{~m}^{2} / \mathrm{pig}$ were selected. Monthly deworming and spraying for ectoparasite control were practised.

Sampling procedure and methodology: A total number of seventy 3 months old, weaned Large White Yorkshire piglets of both sexes were selected and divided into two treatment groups (T1 and T2). The piglets were selected such that all seventy had the similar weight during weaning. The piglets in T1 were offered swill feed and T2 piglets were given swill feed supplemented with chocolate cream waste. The swill (CP 15.28 per cent) feed for T1 group was collected from a college hostel at the rate of $4 \mathrm{~kg} / \mathrm{pig} /$ day. For T2, the swill feed was mixed along with chocolate cream waste and fed at the rate of $4 \mathrm{~kg} / \mathrm{pig} /$ day. The trial was conducted after weaning at eight weeks of age. Body weight was taken with digital weighing balance. Body length was measured as the distance between the anterior edge of the shoulder joint and the point of buttock while, the chest girth circumference was measured immediately behind the forelimbs. All the measurements were made using measuring tape. The backfat thickness was measured using the Renco ultrasound Lean Meater, as described by Cho et al. (2006). Before using the Lean Meater, water was applied on the back of the pigs as a coupling fluid. The backfat thickness value was found using a probe which was moved by the operator's fingers along the hogs flank until the last rib was felt. The probe was placed here from either side of the back bone. The backfat thickness (layer I and II) was read by the instrument in millimetres. The body measurements and backfat thickness were recorded fortnightly. The data collected were subjected to two independent sample Student's ' $t$ ' test for statistical analysis using SPSS version 25.0 as per the method of Snedecor and Cochran (1994).

\section{RESULTS AND DISCUSSION}

The mean \pm S.E of the body weight, body length, chest girth and backfat thickness in layer I and II is given in Table 1 . The proximate analysis of the chocolate cream waste, done in the Department of Animal Nutrition, Madras Veterinary College, is presented in Table 2. The results of statistical analysis are given in Table 1. By statistical analysis it was found that there is significant difference $(P \leq 0.05)$ in body weight and backfat thickness of both T1 and T2 piglets from 105 days till the end of study period. There was no significant difference in body length and chest girth during the study period. This indicates that swill feed supplemented with chocolate cream waste eventually increases the body weight gain. This is in agreement with the findings of McNaughton et al., (1997) and Gustafson and Stern (2003) who summarized that increasing the feed intake or the metabolizable energy increases the body weight gain. According to Gustafson and Stern (2003) cream waste supplemented swill feed eventually enhances growth. Since pig has a digestive tract similar to humans, it makes it capable of consuming food components that people would normally consume (Pond and Maner, 1984). Thus, the incorporation of food wastes and by-products into swine diets is often feasible. The higher weight gain and body measurements in pigs, fed with swill feed supplemented with chocolate cream waste may be due to the higher moisture content and palatability of the cream which might have

Table 1. Showing body weight, body measurements and backfat thickness at different age group of pigs (Values are Mean \pm S.E).

\begin{tabular}{|c|c|c|c|c|c|c|c|c|c|}
\hline \multirow[b]{2}{*}{ Parameters } & & \multicolumn{8}{|c|}{ Measurements taken in fortnight basis } \\
\hline & & $\begin{array}{l}\text { Age } \\
105 \text { days }\end{array}$ & $\begin{array}{l}\text { 't' } \\
\text { value }\end{array}$ & $\begin{array}{l}\text { Age } \\
120 \text { days }\end{array}$ & $\begin{array}{l}\text { 't' } \\
\text { value }\end{array}$ & $\begin{array}{l}\text { Age } \\
135 \text { days }\end{array}$ & $\begin{array}{l}\text { 't' } \\
\text { value }\end{array}$ & $\begin{array}{l}\text { Age } \\
150 \text { days }\end{array}$ & $\begin{array}{l}\text { 't' } \\
\text { value }\end{array}$ \\
\hline \multirow{2}{*}{$\begin{array}{l}\text { Body weight } \\
\text { (kq) }\end{array}$} & T1 & $14.19 \pm 0.45$ & $3.271^{* *}$ & $16.15 \pm 0.51$ & $2.918^{* *}$ & $22.63 \pm 0.71$ & $3.036^{* *}$ & $26.98 \pm 0.56$ & $3.635^{* *}$ \\
\hline & $\mathrm{T} 2$ & $16.49 \pm 0.53$ & $(0.008)$ & $18.308 \pm 0.5$ & $(0.007)$ & $25.26 \pm 0.49$ & $(0.003)$ & $29.59 \pm 0.44$ & $(0.005)$ \\
\hline \multirow{2}{*}{$\begin{array}{l}\text { Body length } \\
(\mathrm{cms})\end{array}$} & T1 & $60.31 \pm 1.48$ & $0.242^{\mathrm{N} s}$ & $65.46 \pm 2.33$ & $0.073^{\mathrm{Ns}}$ & $78.31 \pm 1.08$ & $0.570^{\mathrm{N} s}$ & $85.78 \pm 0.41$ & $2.274^{*^{\prime \prime}}$ \\
\hline & $\mathrm{T} 2$ & $60.99 \pm 2.40$ & $(0.814)$ & $65.70 \pm 2.20$ & $(0.094)$ & $79.48 \pm 1.73$ & $(0.581)$ & $87.03 \pm 0.36$ & $(0.046)$ \\
\hline \multirow{2}{*}{$\begin{array}{l}\text { Chest girth } \\
(\mathrm{cms})\end{array}$} & T1 & $54.35 \pm 1.52$ & $0.812^{\mathrm{N} s}$ & $57.23 \pm 1.76$ & $0.492^{\mathrm{N} s}$ & $67.83 \pm 2.57$ & $0.086^{N s}$ & $78.61 \pm 1.51$ & $2.252^{*^{\prime}}$ \\
\hline & $\mathrm{T} 2$ & $56.10 \pm 1.52$ & $(0.436)$ & $58.43 \pm 1.68$ & $(0.634)$ & $68.15 \pm 2.62$ & $(0.933)$ & $82.41 \pm 0.74$ & $(0.048)$ \\
\hline \multirow{2}{*}{$\begin{array}{l}\text { Backfat thick- } \\
\text { ness (mms) } \\
\text { Layer1 }\end{array}$} & T1 & $5.5 \pm 0.43$ & $2.840^{* *}$ & $6 \pm 0.256$ & $5.00^{* *}$ & $10.33 \pm 0.21$ & $4.472^{* *}$ & $10.67 \pm 0.42$ & $0.958^{\mathrm{Ns}}$ \\
\hline & $\mathrm{T} 2$ & $7.17 \pm 0.40$ & $(0.008)$ & $8.50 \pm 0.43$ & $(0.001)$ & $11.67 \pm 0.21$ & $(0.001)$ & $11.17 \pm 0.31$ & $(0.360)$ \\
\hline \multirow{2}{*}{$\begin{array}{l}\text { Backfat thick- } \\
\text { ness (mms) } \\
\text { Layer2 }\end{array}$} & $\mathrm{T} 1$ & $9.17 \pm 0.31$ & $2.301^{*}$ & $10.17 \pm 0.48$ & $3.402^{* *}$ & $18.50 \pm 0.50$ & $2.591^{*}$ & $17.83 \pm 0.54$ & $7.069^{* *}$ \\
\hline & $\mathrm{T} 2$ & $10.17 \pm 0.31$ & $(0.044)$ & $12.33 \pm 0.42$ & $(0.007)$ & $20.83 \pm 0.75$ & $(0.027)$ & $25.00 \pm 0.85$ & $(0.000)$ \\
\hline
\end{tabular}

Figures in the parenthesis represent $\mathrm{P}$-value, ${ }^{*{ }_{-}-}$significant $(\mathrm{P} \leq 0.01)$ at $1 \%$ level of significance, significant $(P \leq 0.05)$ at $5 \%$ level of significance, Ns- Not significant $(P \geq 0.05)$ 
Table 2. Proximate analysis of chocolate cream waste.

\begin{tabular}{cll}
\hline S.N. & Parameters & Esimate \\
\hline 1. & Moisture & $30.68 \%$ \\
2. & Crude protein & $1.11 \%$ \\
3. & Crude fibre & Not traceable \\
4. & Ether extract & $0.17 \%$ \\
5. & Total ash & $0.66 \%$ \\
6. & NFE & $98.06 \%$ \\
\hline
\end{tabular}

favoured higher feed intake (Adesehinwa and Ogunmodede, 2004 and Murugan et al. 2009). McNaughton (1997) reported that waste chocolate confectionary can be fed to growing swine at inclusion levels up to $30 \%$ of the diet with no adverse effects on growth or carcass quality. Hence this could be concluded that swill feeding supplemented with chocolate cream waste could be used as an alternative feed resource to fattener pig that not only substantially reduces the feed cost but also enhances the growth of pigs.

\section{Conclusion}

The study has compared the effect of swill feed and swill feed supplemented with chocolate cream waste on the body measurements and backfat thickness of fattener pigs. The results indicated that the body weights of swill fed piglets (kg) (T1) at 105 days, 120 days, 135 days and at 150 days were $14.19 \pm 0.45,16.15 \pm 0.51,22.63 \pm 0.71$ and $26.98 \pm 0.56$ respectively. The body weight $(\mathrm{kg})$ of chocolate cream waste supplemented swill feed (kg) (T2) at 105 days, 120 days, 135 days and at 150 days were $16.49 \pm 0.53$, 18.308 \pm 0.5 , $25.26 \pm 0.49,29.59 \pm 0.44$ respectively. The backfat thickness also differed significantly $(P \leq 0.05)$ between the treatment groups indicating that chocolate cream waste supplemented swill feed can be efficiently utilized for the enhanced growth of the fattener pigs.

\section{REFERENCES}

1. Adesehinwa, A.O.K. and Ogunmodede, B.K. (2004). Performance and serum metabolites of growing pigs fed diets containing dusa and cashew nut testa as protein sources. Indian J Anim Sci 74 (1): 113-16

2. Banerjee, G.C. (2010). A textbook of animal husbandry, $8^{\text {th }}$ edition. Oxford and IBH publishing Co. Pvt. Ltd., New Delhi, India, pp.775-836.

3. Cho, S.B., Cho, S.H. Chang, S.S. Chung, I.B. Lim, J.S. Kil, D.Y and Kim, Y.Y. (2006).Effects of restricted feeding on performance, carcass quality and hormone profiles in finishing barrows. Asian-Aust. J. Anim. Sci.19 (11): 1643 - 1648

4. Gustafson, G.M., and Stern, S. (2003). Two strategies for meeting energy demands of growing pigs at pasture. Livest Prod Sci 80: 167-74. https:// doi.org/10.1016/S0301-6226(02)00319-6

5. McNaughton, E. P., Ball, R. O. and Friendship R. M. (1997). The effects of feeding a chocolate product on growth performance and meat quality of finishing swine. Can. J. Anim. Sci. 77(1), 1-8. https:// doi.org/10.4141/A96-055

6. Murugan, M., Mathew, J., Sivakumar, T. and Gnanaraj, P. T.( 2009). Effect of different feeding system on the performance of crossbred pigs. Indian J Anim Sci. 79 (10): 1058-1060. https://www.researchgate.net/ publication/273127975

7. Pond, W. G. and Maner, J. H. 1984. Swine production and nutrition. Chapter 11. AVI Publishing Company, Inc., Westport, CT.

8. Singh, R. R. and Islam, M.M. (2014). Farm Animal Management, $1^{\text {st }}$ ed. New India Publishing Agency. Pvt.,Ltd., India,pp.380.

9. Snedecor, G.W. and Cochran, W.G. (1994). Statistical Methods, $8^{\text {th }}$ ed. Oxford and IBH publishing Co. Pvt. Ltd., New Delhi, India, pp.254-268.

10.Thomas, R., Banik, K., Barman, K., Mohan, N.H. and Sarma, D.K. (2016). Carcass composition and meat quality parameters of Ghungroo pigs. Indian J Anim Sci. 86 (8): 925-929. https://www.researchgate.net/ publication/306495593 